\title{
NATURE
}

\section{A Step in the Right Direction}

THE first thing to be said about last week's statement on nuclear power policy by Mr John Davies, Secretary of State for Trade and Industry (see Nature, 238, 303; 1972), is that it has removed some of the uncertainty that has shrouded the industry for the past twenty months. Britain is not to buy American pressurized water reactors immediately, even if the possibility of doing so some time in the next decade has not been completely ruled out. Also, the advanced gas cooled reactors are not to be condemned out of hand, and the high temperature reactor may yet be fully developed with help from the Germans.

Although the present government is most immediately to blame, the history of muddle about the British nuclear power industry goes back for the best part of two decades, to the point in 1955 at which the then government, acting on the advice of the Atomic Energy Authority and the Central Electricity Generating Board, decided to set up four consortia of industrial companies to construct the gas-cooled reactors which, it was then thought, would soon be springing up like mushrooms in Britain and in export markets abroad.

It is now clear, however, that the government's concept of partnership between the AEA and the CEGB and the industrial consortia was nothing like as equitable as it should have been. Between them, the public corporations remained responsible for research, development and a good deal of the detailed design of the reactors which have since been developed. The industrial consortia were torn by the sense of impotence which this arrangement gave them and the heady prospect of profitable sales without commensurate expenditure on innovation. But, in the event, the export markets have not materialized, new designs have succeeded each other more quickly than the domestic market could usefully absorb them, the number of consortia has shrunk from four to two as commercial prospects have dimmed and now a further amalgamation into one is promised. Throughout this period, the Atomic Energy Authority, technically as good as any comparable organization in the world, has been superbly confident of its judgement of what the market needs, and in spite of the unwillingness of the CEGB to buy reactors (such as the advanced gas-cooled reactor) which it thought it might not need, the result is that after twenty years and the expenditure of nearly as much on reactor development as on Concorde (which is an even less good bargain), nobody can be sure whether the British nuclear industry is now in a position to sell reactors successfully. For the past five years, it has also been apparent that there is a necessary connexion between the scale of nuclear research and development in Britain and the potential profitability of the market and, while some parts of the AEA have been reorganizedfuel manufacturing has been, for example, split off to British Nuclear Fuels Limited -the part of the AEA concerned principally with the development and design has languished in an awkward limbo, unsure of its role.

The biggest conundrum left unsettled is how the government will arrange to subsidize those kinds of research and development which may, in the long run, be exceedingly important but which lie beyond the timescales of organizations like that to be set up. To be sure, $\mathrm{Mr}$ Davies has promised $£ 15$ million for component design for the fast breeder reactor but presumably the government is going to have to continue subsidizing work like this for several years with a simple subvention for research and development. That is something that it must grit its teeth and bear. If there should be difficulties in a proposal that private enterprises should benefit by continuing injections of public money, they should be suppressed. But it is also essential that subventions of this kind should not be hand to mouth affairs but, rather, deliberate decisions validted against publicly declared plans for research and development which will last for the decade or so required to carry through long-term development. In short, the government should declare what might and should happen to the long-term development of nuclear power in Britain. The past few decades, it is true, have been a disappointment, but only a relative disappointment; it would be foolish to discard what has been done for the sake of a commercial principle.

The most serious drawback in the arrangements which the government now proposes is that the time may well have passed when the creation of large industrial consortia for building nuclear power stations is a sensible procedure. Public utilities are now much better placed than they were fifteen years ago to place orders for the separate components of a nuclear power station, with the result that the massive turnkey contracts of the past are likely to tail away. It is true that thoroughly competent design organizations may be able to function as consulting engineers used to do half a century ago, and plainly a central organization has the advantage that it may be used more effectively to administer safeguards and the continuing supply of fuel. It will be some time before anybody can guess how fully the British Government's new proposal for one large consortium meets this need.

The question of whether the immediate future-the next ten years-will see the building of nuclear reactors on the old-fashioned British style is more problematical, and the recent CEGB statement that it only foresees the need for at most four nuclear power reactors by 1982 has only clouded the issue, for predictions of power needs are notoriously unreliable. Whatever the type of thermal reactor the government and industry between them decide to build in the period before the fast breeder reactors become commercially available, few crocodile tears should be shed over the decision. If the government creates a viable industry by providing funding for the fast breeder reactor, then the frustrations of the past few years will soon be forgotten. 